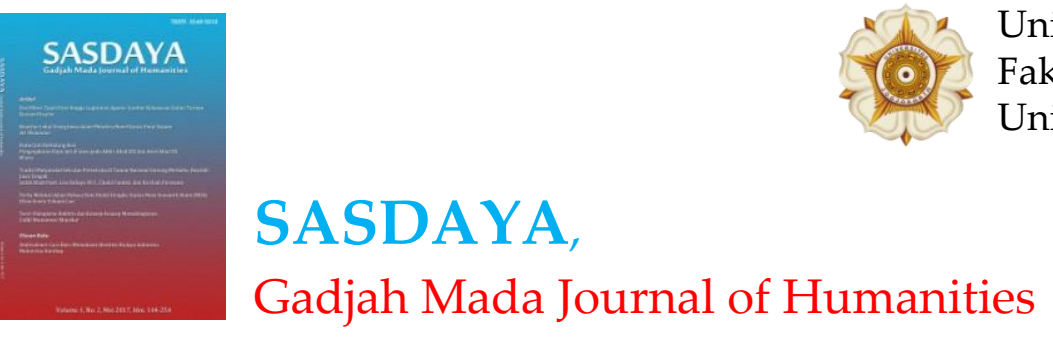

ISSN: 2548-3218 (print); ISSN : 2549-3884 (online); website: https://jurnal.ugm.ac.id/sasdayajournal

- Gardu dalam 'Struktur' Politik di Indonesia

Sebentuk Pertemuan Historisisme, Strukturalisme Levi-Strauss dan Posmodernisme (?)

Gardu in 'Structure' of Politics in Indonesia:

A form Meeting of Historicism, Structuralism of Levi-Strauss and Postmodernism

Penulis/Author(s): Asti Kurniawati

Sumber/Source :SASDAYA, Gadjah Mada Journal of Humanities, Vol. 2, No. 2 (May 2018), pp. $451-470$

- Penerbit : Unit Penelitian dan Publikasi Fakultas Ilmu Budaya

Universitas Gadjah Mada, Indonesia

Copyright (c) 2018 SASDAYA: Gadjah Mada Journal of Humanities

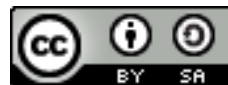

This work is licensed under a Creative Commons Attribution-ShareAlike 4.0 International License. 


\title{
GARDU DALAM 'STRUKTUR’ POLITIK DI INDONESIA \\ Sebentuk Pertemuan Historisisme, Strukturalisme Levi-Strauss dan \\ Posmodernisme (?)
}

\author{
Asti Kurniawati ${ }^{1}$
}

\begin{abstract}
This article aims to examine the possibility of meeting three paradigms of Historicism, Structuralism of Levi-Strauss and Posmodernism by analyzing the book of Abidin Kusno, Penjaga Memori; Gardu di Perkotaan Jawa, using the paradigm of Levi-Strauss structuralism, exploring the paradigm that used by the author and the philosophy behind the writing history. This step was done to find out the possible paradigm meeting between those used by the author of the book and the Levi-Strauss structuralism paradigm that used to analyze the book.
\end{abstract}

Key words: Historicism, Structuralism of Levi-Strauss and Posmodernism

\section{PENDAHULUAN}

Analisis-analisis yang dilakukan Levi-Strauss dan pengikutnya terhadap mitosmitos dan karya-karya sastra memunculkan ide untuk menerapkannya pada karya sejarah. Hal ini karena mitos dan karya sastra pada dasarnya adalah cermin atau miniatur dari sebuah fenomena sosial budaya, yang artinya juga bisa mewakili sebuah fenomena sejarah. Untuk mendapatkan jawaban atas pertanyaan tersebut, saya mengambil langkah dengan mencoba menganalisis satu karya sejarah menggunakan paradigma strukturalisme Levi-Strauss, menelisik paradigma yang digunakan penulis dan filsafat dibalik karya tersebut. Dengan demikian, dimungkinkan ditemukannya suatu pertemuan paradigma antara yang digunakan oleh penulis buku dengan paradigma strukturalisme Levi-Strauss yang digunakan untuk membedah karya tersebut.

Karya sejarah yang terpilih adalah buku karya Abidin Kusno yang berjudul Penjaga Memori; Gardu di Perkotaan Jawa, terbitan Ombak, 2007. Banyak karya sejarah, tapi mengapa buku Abidin Kusno yang saya pilih? Terdapat beberapa alasan, diantaranya adalah ketika saya membaca buku ini, saya menangkap adanya pola-pola dalam politik ruang yang menempel pada "gardu" dalam setiap periode yang dikemukakan. Struktur atau pola itu tidak digambarkan menggunakan diagram sehingga tidak tertangkap secara nyata oleh pembaca. Barangkali si penulis juga tidak

1 Program Studi Ilmu Sejarah, Fakultas Ilmu Budaya, Universitas Sebelas Maret, Surakarta. Alamat email: astikurniawati.fib@gmail.com 
menyadari bahwa analisis yang dilakukannya terhadap gardu menghadirkan struktur politik dari periode ke periode. Oleh karena itu, saya berasumsi bahwa terdapat struktur dalam bawah sadar penulis dalam menganalisis keberadaan gardu yang bisa ditampilkan dengan menggunakan strukturalisme Levi-Strauss. Deep structure ini bisa jadi juga terdapat dalam diri penguasa, sebagai penentu kebijakan atas fungsi-fungsi gardu.

Sebagai seorang arsitek, saya berasumsi bahwa pola pikir Abidin Kusno sangat strukturalis, meskipun dilihat dari beberapa tulisannya, tema yang diangkat adalah isu-isu yang biasanya menjadi perhatian kaum posmodernis. ${ }^{2}$ Oleh karena itu, dalam melihat tulisannya, saya harus membebaskan diri dari pandangan yang menertentangkan strukturalisme dengan posmodernisme.

Jika historisisme merupakan sebuah paradigma dengan salah satu asumsi dasarnya adalah deskripsi perubahan dan periodisasi, maka setiap tulisan sejarah pastilah berada pada wilayah paradigma dan filsafat historisisme. Jika memang demikian, berarti sangat dimungkinkan dalam satu tulisan digunakan dua atau lebih paradigma, sehingga paradigma yang digunakan misalnya menjadi historisisme posmodernis. Yang menjadi pertanyaan adalah mungkinkah muncul historisisme strukturalis, atau bahkan posmodernisme strukturalis?

Jika kita melihat historisisme adalah sebuah paradigma yang berdiri sendiri, maka kemungkinan munculnya historisisme strukturalis sepertinya tidak akan terjadi. Terlebih ketika historisisme yang mengutamakan kronologi dan periodisasi dipertentangkan dengan strukturalisme yang bersifat sinkronis. Demikian pula, ketika posmodernisme dimaknai sebagai anak dari pos-strukturalisme, maka pertemuan antara posmodernisme dan strukturalisme tidak mungkin terjadi juga. Namun, ketika posmodernisme dimaknai sebagai sebuah penolakan terhadap narasi besar atau metanarrative, pertemuan keduanya tentunya dimungkinkan. ${ }^{3}$

Penolakan terhadap narasi umum memungkinkan berkembangnya varisai tema penelitian. Tema-tema kecil menjadi bahan kajian, dan menampilkan keunikankeunikan setiap fenomena sosial budaya. Namun, bukankah keunikan-keunikan itu tidak berarti bahwa tidak menghadirkan pola? Jika egoisme aliran pemikiran bisa dihilangkan dan dialog antar paradigma berjalan dengan "tanpa dendam", saya kira antara posmodernisme, strukturalisme dan historisisme bukanlah sesuatu yang harus saling dijauhkan. Mereka bisa bertemu dengan caranya masing-masing. Apalagi ketika strukturalisme Levi-Strauss tidak secara kaku mempertahankan metode kerja yang harus sampai pada deep structure, namun bisa hanya sampai pada pencarian atau pembangunan struktur, maka historisisme struktural sangat dimungkinkan keberadaannya, bahkan untuk mengkaji tema-tema kecil.

2 Beberapa karya-karya Abidin Kusno yang lain diantaranya adalah Ruang Publik, Identitas dan Memori Kolektif: Jakarta Pasca-Soeharto (Yogyakarta: Ombak, 2009), Behind the Postcolonial, Architecture, Urban Space and Political Cultures in Indonesia (London and New York, Routledge, 2000), Zaman Baru Generasi Modernis, Sebuah Catatan Arsitektur (Yogyakarta: Ombak, 2012)

${ }^{3}$ Ritzer, George dan Goodman, Douglas J., Teori Sosiologi Modern (Jakarta: Kencana Prenada Media Group, Edisi ke-6, Cetakan ke-5, 2008), hlm. 601-653. 
Analisis terhadap karya Abidin Kusno ini diharapkan dapat menguji hipotesis liar tentang pertemuan antara strukturalisme Levi-Strauss yang sering difahami ahistoris, posmodernisme dan historisisme.

\section{PARADIGMA STRUKTURALISME}

Paradigma dalam penulisan sejarah identik dengan kerangka berfikir. Paradigma merupakan konsep yang digunakan untuk menganalisis suatu fenomena historis, dan ini lebih dekat dengan teori atau konseptualisasi dari beberapa teori. Sejarawan (baca: muda) sepertinya sedikit yang terbiasa berjibaku dengan dialog-dialog epistimologis ilmu-ilmu sosial budaya. Oleh karena itu, tulisan sejarah lebih banyak diwarnai oleh tafsir dan atau analisis dengan meminjam teori ilmu-ilmu lain. Apakah hal ini karena sejarawan secara otomatis bekerja di wilayah filsafat historisisme, sehingga dialog itu sudah final? Bagaimana perkembangan aliran filsafat ilmu-ilmu sosial budaya mempengaruhi tafsir, interpretasi atau analisis sejarawan yang berada pada zaman yang berbeda-beda?

Pada kenyataannya, tulisan dan metodologi sejarah berkembang mengikuti tren wacana keilmuan. Ilmu sejarah menjadi bagian yang berdialog dengan zaman. Arus positivisme sempat mewarnai tulisan-tulisan sejarah. Pada perkembangannya, era posmodernisme juga mewarnai karya-karya sejarah. ${ }^{4}$ Namun, sepertinya semuanya mengalir begitu saja. Jurusan ilmu sejarah di Indonesia tidak secara tegas mengajarkan mahasiswanya untuk memilih pijakan di antara filsafat-filsafat ilmu yang ada. Oleh karenanya, tidak jarang tulisan-tulisan sejarah berada di antara beberapa filsafat-filsafat dasar dengan tanpa disadari.

Strukturalisme Levi-Strauss merupakan salah satu paradigma yang tidak poluler di sejarah. Namun, sebagian sejarawan menyadari pentingnya ditemukan pola dalam sejarah yang ditulis. Jika pun bukan dalam satu karya sejarah, paling tidak dalam beberapa atau banyak tulisan sejarah dapat ditemukan suatu pola sehingga sejarah dapat bermanfaat untuk menyelesaikan persoalan masa kini. ${ }^{5}$

Bagaimana sejarah bisa menghadirkan pola? Sepertinya diperlukan dialog antara sejarah (yang barangkali semua dimasukkan ke dalam historisisme) dengan strukturalisme. Asumsi inilah yang membawa saya mengujicobakan strukturalisme Levi-Strauss untuk menganalisis karya sejarah. Karena analisis ini dilakukan terhadap karya sejarah dan bukan fenomena sejarah, maka struktur-struktur yang akan tertangkap adalah struktur yang secara tidak sadar dibangun oleh penulis, yang barangkali memang adalah struktur bawah sadar masyarakat yang ditulis.

Menurut Kuntowijoyo, konsep structure masuk dalam khasanah ilmu sejarah melalui tradisi pemikiran strukturalis (Marxisme dan Strukturalisme). Para pemikir strukturalis mempunyai tingkat kesamaan pemahaman bahwa struktur bersifat

\footnotetext{
${ }^{4}$ Salah satu contoh hasil-hasil penulisan sejarah tersebut adalah karya yang diedit Henk Schulte Nordholt, Bambang Purwanto, dan Ratna Saptari (ed), Perpektif Baru Penulisan Sejarah Indonesia (Jakarta: Yayasan Obor Indonesia, KITLV-Jakarta, Pustaka Larasan, 2008).

${ }^{5}$ Kuntowijoyo, Pengantar Ilmu sejarah (Yogyakarta: Bentang, 1995).
} 
abstrak (hanya suatu konstruksi mental); ada hubungan antara struktur dan dunia nyata; dan orang harus menembus ke bawah untuk menemukan struktur. ${ }^{6}$ Konsep yang sama dikemukakan oleh Heddy Shri Ahimsa-Putra bahwa terdapat struktur di dalam bawah sadar masyarakat pemilik mitos, ada struktur di bawah sadar penulis karya sastra, yang itu bisa diungkap menggunakan paradigma strukturalisme LeviStrauss. ${ }^{7}$

Konsep tentang struktur-struktur pikiran manusia seringkali dikritik tidak historis. Namun, menurut Anthony Giddens, kritikan itu jelas gagal. Strukturalisme Levi-Strauss persisnya menyuarakan secara efektif apa yang kemudian disebut Fouchault sebagai 'arkeologi', menggali di bawah kesadaran historis budaya 'panas' sampai lapisan terdalam temporalitas yang mencirikan bentuk-bentuk budaya yang telah mendominasi 'sejarah' manusia. ${ }^{8}$

\section{GARDU DI PERKOTAAN JAWA DARI MASA KE MASA}

"Jika ada suatu bangunan yang terlupakan dalam melihat dan membahas arsitektur dan perkotaan kita, mungkin gardu adalah bangunan itu". Demikianlah Abidin Kusno menulis dalam pengantarnya. Tulisan tentang gardu memang menjadi menarik untuk dibaca karena bangunan kecil ini tidak mendapat perhatian dalam kajian arsitektur, bahkan juga dalam kajian bidang-bidang lain, termasuk sejarah dan politik. Padahal keberadaan gardu telah melintasi beberapa zaman dalam sejarah perjalanan Bangsa Indonesia.

Menurut pengamatan Abidin Kusno, gardu mengalami metamorfosis dari waktu ke waktu, beradaptasi dalam menghadapi sejarah Indonesia yang penuh pancaroba. Gardu hadir dalam identitas yang berubah-ubah.

Sejarah keberadaan gardu ditelusuri hingga zaman sebelum datangnya kolonialisme Eropa. Gardu bisa dijumpai di pintu masuk kediaman bangsawan atau orang-orang terkemuka. Tujuan didirikannya gardu zaman pra-kolonial bukanlah untuk memberi batas teritorial maupun pertahanan atau pengusiran, melainkan untuk menunjukkan kuasa raja sebagai pusat kosmos.

Pada masa kolonial, gardu identik dengan penguasaan ruang oleh penguasa kolonial. Pembangunan jalan (groote weg) yang dijalankan Herman Willem Daendels menghadirkan gardu sebagai institusi kolonial, yang memberikan batas-batas teritorial.

Pada masa Jepang, gardu masih memainkan perannya dalam "mobilisasi dan kontrol". Pemerintah militer Jepang terus-menerus menggunakan Keibodan dan

\footnotetext{
${ }^{6}$ Kuntowijoyo, Penjelasan Sejarah (Historical Explanation) (Yogyakarta: Tiara Wacana, 2008), hlm. 59.

7 Tentang paradigma strukturalisme Levi-Strauss dan contoh-contoh aplikasinya bisa dilihat Heddy Shri Ahimsa-Putra, Strukturalisme Levi-Strauss. Mitos dan Karya Sastra. (Yogyakarta: Kepel Press, Cetakan Ketiga, 2013).

8 Anthony Giddens, "Strukturalisme, Pos-Strukturalisme dan Produksi Budaya, Anthony Giddens dan Jonathan Turner, Social Theory Today. Panduan Sistematis Tradisi dan Tren Terdepan Teori Sosial (Yogyakarta: 2008), hlm. 363.
} 
memilih para pemimpin lingkungan kota dan desa di Jawa sebagai alat agar pelaksanaan tugas unit-unit lingkungan tersebut menjadi serasi. Selain itu, mereka menggunakan gardu untuk menyelaraskan pengawasan rumah tangga. Gardu juga berfungsi sebagai tempat pertemuan.

Pada masa revolusi, terdapat "pos-pos komando" yang digunakan sebagai tempat pemeriksaan sekaligus merupakan tapal-tapal batas wilayah negara Indonesia. Praktek gardu yang disesuaikan selama masa Jepang ditumpahkan di era revolusi.

Di era Soeharto, gardu disebut pos hansip (pertahanan sipil). Gardu dalam bentuk pos hansip dirasakan sangat dibutuhkan di Jakarta. Hal ini menandai suatu wacana bahwa Jakarta tidak lagi aman. Berbagai tempat seperti bank-bank, pusatpusat perbelanjaan, kompleks-kompleks perumahan baru, maupun rumah-rumah kalangan elit menyewa satpam-satpam.

Wajah gardu tiba-tiba menyolok menjelang Pemilu 1999. Kekacauan pasca lengsernya Soeharto memicu meningkatnya jumlah gardu dan gerbang secara berlipat ganda. Hal ini dimanfaatkan oleh para elit Partai Demokrasi Indonesia Perjuangan (PDI-P) untuk menarik perhatian publik. Bahkan, tokoh-tokoh PDI-P yang diketuai Megawati Sukarno Putri memprakarsai pembangunan gardu yang popoler disebut posko (pos komunikasi) di berbagai tempat di seluruh pelosok negeri.

Demikianlah sekilas perjalanan gardu yang dipaparkan Abidin Kusno. Namun Abidin Kusno tidak mengawalinya dengan penelusuran keberadaan gardu dari zaman pra kolonialisme Barat dan ditarik ke zaman kontemporer, melainkan mengawalinya dengan mengkaji keberadaan gardu yang jumlahnya bertambah secara cepat pasca 1998, dan ditarik ke masa silam.

Lebih jauh, yang dilakukan Abidin Kusno adalah menelisik fungsi-fungsi politik dan perubahan makna gardu, secara genealogis dari masa kini ke masa silam. Selain itu, juga menyajikan bagaimana gardu masih terus menjadi sebuah medium visual yang melaluinya ingatan-ingatan kolektif dibentuk dan ditransformasikan melintasi tatanan-tatanan historis yang berbeda. Demikianlah secara sekilas kajian tentang gardu tersebut menyiratkan adanya pola-pola atau struktur-struktur yang terbangun.

\section{STRUKTUR SEPUTAR GARDU}

Dari judulnya, yaitu Penjaga Memori; Gardu di Perkotaan Jawa telah menunjukkan bahwa Abidin Kusno meletakkan gardu sebagai monumen, penjaga memori. Melalui gardu, masyarakat akan mengingat sesuatu. Apa yang diingat dan bagaimana ingatan itu terbentuk, sepertinya akan lebih mudah difahami ketika struktur-struktur atas fenomena gardu tersebut diungkap.

Struktur-struktur seputar gardu berkaitan dengan sistem sosial dan politik di Indonesia. Abidin Kusno menempatkan gardu, si bangunan kecil itu ke dalam politik ruang.

\section{Gardu, Penguasa, dan Massa}

Relasi yang paling dominan tertangkap dalam tulisan Abidin Kusno adalah relasi antara gardu dan penguasa. 
"Pasca turunnya Soeharto ketika komunitas kota meresposn kekacauan yang terjadi dengan pendirian gardu-gardu, para elit politik di Indonesia memanfaatkannya sebagai upaya menarik perhatian publik. Bahkan, tidak hanya memanfaatkan, tokoh-tokoh politik Partai Demokrasi Indonesia Perjuangan/PDI-P, yang diketuai Megawati Sukarno Putri memprakarsai pembangunan gardu yang populer disebut posko (pos komunikasi) di berbagai tempat di seluruh pelosok negeri."

Barangkali PDI-P memaknai gardu sebagai representasi dari ruang orang-orang kecil yang harus dikuasai jika ingin menang pemilu. Melalui ruang itulah antara penguasa dan rakyat "dirancang" oleh PDIP untuk bertemu. Gambar Soekarno dan Megawati dihadirkan dan seolah-olah hadir secara sungguh-sungguh di tengah massa. Bahkan, gardu tidak hanya digunakan oleh PDI-P sebagai media komunikasi dengan rakyat, melainkan juga dihadirkan sebagai podium, yang seolah-olah Sukarno, presiden pertama Indonesia yang sangat terkenal dengan orasi politiknya berdiri disana. Gardu diidentikan dengan podiom, tempat penguasa berbicara kepada rakyatnya.

Mengapa PDI-P bisa dikategorikan sebagai penguasa, dalam arti kuasa atas makna dan ruang/posko (gardu), padahal belum menang pemilihan umum? Karena PDI-P adalah partai yang mengklaim dirinya sebagai pihak yang ditindas oleh Orde Baru. Ketika Orde Baru tumbang, maka pihak yang tertindas itu dengan sendirinya akan mendapatkan ruang gerak yang leluasa. Hal ini dibuktikan dengan penguasaan atas ruang-ruang publik yang disebut gardu. Bangunan kecil ini tidak hanya dijadikan pos-pos komunikasi tetapi juga menjadi ruang untuk memrepresentasikan citra publik dirinya dan sang ayah, Sukarno. Ia menginstruksikan kepada semua yang ikut atau bersimpati dengan partainya agar menjaga posko, menggunakannya dengan baik sebagai pusat pendidikan, dan menghindari tindakan apapun yang bisa mencederai citra posko.

Dari penjelasan di atas, kita bisa membayangkan adanya tangan penguasa pada gardu di perkotaan. Jadi bisa digambarkan strukturnya sebagai berikut:

\section{PDI-P (Penguasa) $\longrightarrow$ Posko (Gardu) $\longrightarrow$ Rakyat/Massa}

Pada era Soeharto, gardu tampil sebagai pos hansip. Soeharto tidak menggunakan istilah posko untuk gardu. Posko atau pos komando digunakan dalam konteks pertempuran di "medan perang". Ia dibangun secara temporer oleh unit-unit militer saat mereka bertugas di wilayah-wilayah yang rawan dan belum terkendali. Oleh karena itu, posko di era Soeharto menjadi simbol ancaman dan ketidakamanan. Namun, ketidakamanan itu tidak berada di kota, melainkan di desa. Maka poskoposko awal pemerintahan Soeharto tidak berada di perkotaan. Barulah pada tahun 1980-an, kota dinilai lebih berbahaya daripada desa. Maka pos-pos keamanan di bangun di kota. Namun pos-pos keamanan itu tidak lagi berupa pos komando militer, melainkan bertransformasi menjadi pos-pos hansip. Fungsinya tidak berubah, yaitu sebagai pengontrol ketertiban dan keamanan. Dalam kasus pos hansip di luar Jawa, 
fungsinya sama dengan yang disebut terakhir, sebagai control atas ketertiban dan keamanan.

Jadi, di era Soeharto tidak digunakan istilah posko untuk gardu, namun kehadiran gardu-gardu hansip di berbagai tempat seperti bank, pusat-pusat perbelanjaan, kompleks-kompleks perumahan baru maupun di rumah-rumah kalangan elit merupakan transformasi dari posko militer yang sebelumnya berada di desa. Namun fungsinya tetap sama yaitu mengumpulkan berbagai informasi, memantau setiap gerakan, dan memonitor aksi "pembersihan" segala bentuk potensi yang mengancam kota. Melalui gardu, penguasa menawarkan ketertiban, keteraturan dan keamanan kepada warganya.

Meskipun pos-pos keamanan telah "dipindahkan" dari desa ke kota, namun gardu di desa masih menjadi simbol keteraturan yang ditawarkan di kota. Abidin Kusno menampilkan baliho yang dipasang di Jakarta, bergambarkan Soeharto sedang memberi instruksi melalui radio, dengan latar belakang suasana desa. Ditempatkan di tengah Kota Jakarta, baliho dimaknai Abidin Kusno sebagai media yang memberi informasi kepada warga kota tentang kondisi keamanan di desa dan juga merepresentasikan suatu hasrat bahwa kondisi semacam itu terimplementasikan di kota. Dengan dipasang tahun 1980-an kala Indonesia sedang menapaki tahapan penting "perkembangan" nasional dan persis pada saat yang sama ketika tindakantindakan pengamanan terstandardisasi diterapkan di kota.

Pengamanan dan pendisiplinan tidak hanya berlaku di kampung, melainkan juga merambah kelas menengah. Menjelang 1980-an, pasar real estate Jakarta untuk perumahan kota mulai menganggap keamanan sebagai komponen utama dalam penjualan perumahan kota baru. Gerbang masuk yang begitu besar dengan pos hansip yang dilengkapi penjaga-penjaga keamanan merupakan bangunan pertama yang dibangun pengembang ketika mulai memasarkan perumahan.

Terdapat struktur yang sama dengan pemanfaatan gardu di era reformasi, meskipun pesan yang disampaikan berbeda.

\section{Soeharto (Penguasa) $\longrightarrow$ Pos Hansip (Gardu) $\longrightarrow$ Rakyat}

Tahun 1990-an wacana keamanan dan ketertiban yang merasuk di alam fikir warga kota, pos hansip yang menyatu dengan gedung-gedung dan lingkunganlingkungan pemukiman telah menjadi corak perkotaan yang sudah tidak asing lagi bagi penduduk Jakarta. Abidin Kusno melihatnya sebagai simbol keamanan dan ketertiban yang terkait dengan kekuasaan rezim. Betapapun bermacamnya bentuk pos-pos hansip dalam ruang fikir publik, mereka semua tersambung dalam satu sumber, yaitu negara. Dari sini, negara memancarkan suatu gugusan makna yang lain yang diasosiasikan dengan modal swasta, bisnis korporasi swasta, dan prestige "kelas menengah" serta ketakutan mereka pada jalanan.

Jauh sebelum periode-periode yang dijelaskan di atas, gardu sudah tampil di Jawa sebelum datangnya kolonialisme Eropa. Gardu bisa dijumpai di pintu masuk kediaman bangsawan atau orang-orang terkemuka. Akan tetapi, tujuan didirikannya gardu pada zaman pra-kolonial bukanlah untuk memberi batas teritorial maupun untuk pertahanan atau pengusiran. Maksud kehadiran gardu itu adalah demi 
menunjukkan kuasa raja sebagai pusat kosmos. Dengan demikian gardu gardu di masa pra-kolonial adalah simbol kekuasaan juga, meskipun secara nyata tidak menyimbolkan suatu penguasaan atas wilayah secara nyata, namun lebih dari itu justru sebuah kekuasaan yang 'tanpa batas'. Jadi keberadaan gardu di Jawa sejak awal ternyata telah memiliki relasi dengan penguasa. Pesan penguasa yang disampaikan kepada rakyat melalui gardu adalah posisi penguasa sebagai pusat kosmos. Relasi itu bisa digambarkan melalui struktur di bawah ini.

\section{Bangsawan (Penguasa) $\longrightarrow$ Gardu $\longrightarrow$ Rakyat}

Periode kolonial, citra gardu tidak semata-mata digerakkan oleh wacana kolonial tentang keamanan, namun juga melibatkan representasi kekuasaan, wilayah, maupun identitas. Demikianlah suatu budaya gardu diciptakan oleh penguasa kolonial sejak abad ke-19. Gardu merepresentasikan munculnya negara kolonial di Jawa, yang mereorganisasi ruang di desa dan kota.

Munculnya gardu dan peran yang dimainkannya dalam institusi ronda (baik siang maupun malam) adalah dampak dari tatanan-tatanan yang dicanangkan Daendels, yaitu orang yang memiliki proyek pembangunan Jalan Pos Besar untuk mengembangkan jalinan komunikasi antar karesidenan, memperluas wilayah ekonomi dan memudahkan aktivitas pengamanan terhadap aksi-aksi pemberontakan di beberapa daerah tertentu di Pulau Jawa. Pada jalan itulah terdapat gardu kolonial, yang didirikan sepanjang jalan dengan interval yang tetap $(9 \mathrm{~km})$ untuk para musafir yang butuh mengganti kuda-kuda mereka. Yang menarik adalah bangunan gardu kolonial itu mewujud dalam bentuk pendhopo. Jika sebelumnya pendhopo adalah bangunan para elit Jawa, Daendels mengalihkannya untuk kepentingan Groote Postweg, yang berarti jalan tersebut menyajikan simbolisme dan fungsi pendhopo demi meraih perhatian dan pengaruh di Jawa. Melalui gardu yang dibangunnya, kolonial meminjam simbol penguasa pribumi untuk mengabarkan wilayah kekuasaannya. Gardu di sepanjang Jalan Pos Besar merupakan media komunikasi pihak kolonial kepada massa, baik pribumi maupun non pribumi. Melalui gardunya, penguasa kolonial menyampaikan hegemoninya terhadap ruang-ruang tersebut. Lebih dari sekedar itu, pembangunan Jalan Pos Besar yang dilengkapi dengan gardu-gardu berwajah pendhopo seolah-olah menyampaikan otoritas tradisional Jawa yang telah runtuh sejak abad ke-18.

Struktur yang bisa kita tangkap dari relasi antara gardu dan penguasa di zaman kolonial sama dengan relasi yang terbangun di periode-periode yang lain.

\section{Kolonial (Penguasa) $\longrightarrow$ Gardu $\longrightarrow$ Rakyat/Massa}

Terdapat satu periode lagi yang menurut Abidin Kusno memiliki peran penting dalam sejarah gardu di Indonesia. Periode tersebut adalah periode Jepang.

Berbeda dengan cita-cita Belanda yang ingin mewujudkan kolonisasi yang "damai' di Hindia, kekerasan mewarnai periode Pemerintahan Militer Jepang di Indonesia. Gardu-gardu jaga di kota menjadi ruang-ruang yang dikuasai Jepang dan digunakan untuk "mengabarkan" kekuasaannya. Orang Indonesia diinstruksikan 
untuk berhenti dan memberi hormat kepada penjaga kota. Gardu merepresentasikan struktur komando dan aparat-aparat pedagogis Pemerintahan Militer Jepang. Jepang mendirikan gardu-gardu di titik-titik strategis untuk menciptakan fokus visual permanen bagi mereka yang melintas di jalan, sehingga mereka bisa melihat otoritas baru dan mengetahui dimana hormat harus dilaksanakan. Dengan demikian, sangat nyata bahwa gardu di masa Jepang digunakan untuk mengabarkan kepada rakyat jajahan tentang hadirnya penguasa atau otoritas baru. Lebih dari itu, gardu dimanfaatkan untuk "menyampaikan" instruksi-instruksi militeristik kepada rakyat. Dari pemaparan Abidin Kusno tersebut, kita bisa menyusun bangunan relasi antara penguasa (Jepang), gardu dan rakyat jajahan.

\section{Jepang (Penguasa) $\longrightarrow$ Gardu $\longrightarrow$ Rakyat Jajahan}

Dilihat dari struktur-struktur tersebut, sebenarnya penguasa selalu menempatkan gardu pada fungsi yang sama. Ia adalah alat komunikasi penguasa kepada rakyatnya. Komunikasi antara penguasa dengan rakyat melalui gardu tidak terbangun sebaliknya. Rakyat tidak bisa menyampaikan pesan kepada penguasa melalui gardu. Gardu yang berdiri di tengah-tengah kehidupan rakyat adalah institusi milik penguasa, bukan institusi 'milik' rakyat.

Soekarno secara eksplisit tidak terlihat menggunakan gardu sebagai media komunikasi. Barangkali karena Sukarno memiliki podiom yang lebih efektif dan langsung dalam menyampaikan pesannya kepada rakyat. Namun, gardu menjadi "milik" TNI dan pemuda. Mereka bisa dimaknai sebagai wakil dari penguasa dalam konteks ruang yang sesungguhnya, meskipun Sukarno sebagai pemimpin memiliki media sendiri untuk hadir di tengah rakyat. Realitas-realitas penguasaan ruang yang dilakukan TNI dan pemuda seakan-akan menjadi media untuk menunjukkan kepada rakyat Indonesia tentang ide-ide revolusi dan dekolonisasi yang disampaikan Sukarno dalam pidato-pidatonya. Dengan demikian, masih bisa dimaknai bahwa gardu-gardu pemuda masa revolusi adalah milik penguasa, dimana penguasa itu bisa diartikan Sukarno, TNI atau pemuda, sehingga relasinya sebagai berikut.

\section{Sukarno, TNI atau pemuda $\longrightarrow$ Gardu $\longrightarrow$ Rakyat Indonesia}

Demikianlah relasi antara gardu dengan penguasa terbentuk karena penguasa memanfaatkan gardu sebagai media menyampaikan pesan kepada rakyatnya.

Dari struktur-struktur yang ditemukan diatas, kita bisa melihat bahwa barangkali tanpa disadari, Abidin Kusno telah menghadirkan suatu bentuk transformasi struktur gardu dari waktu ke waktu. Hal ini berarti Abidin Kusno menghadirkan transformasi yang bersifat historis.

Agar kita dapat melihat lebih jelas bagaimana transformasi itu terjadi, bisa digambarkan melalui struktur di bawah ini. Meskipun Abidin Kusno menyajikan ulasan gardu dimulai dari periode kontemporer ke masa kolonial, saya akan membangun struktur transformasi tersebut dengan sebaliknya, agar transformasi historisnya lebih mudah difahami. 


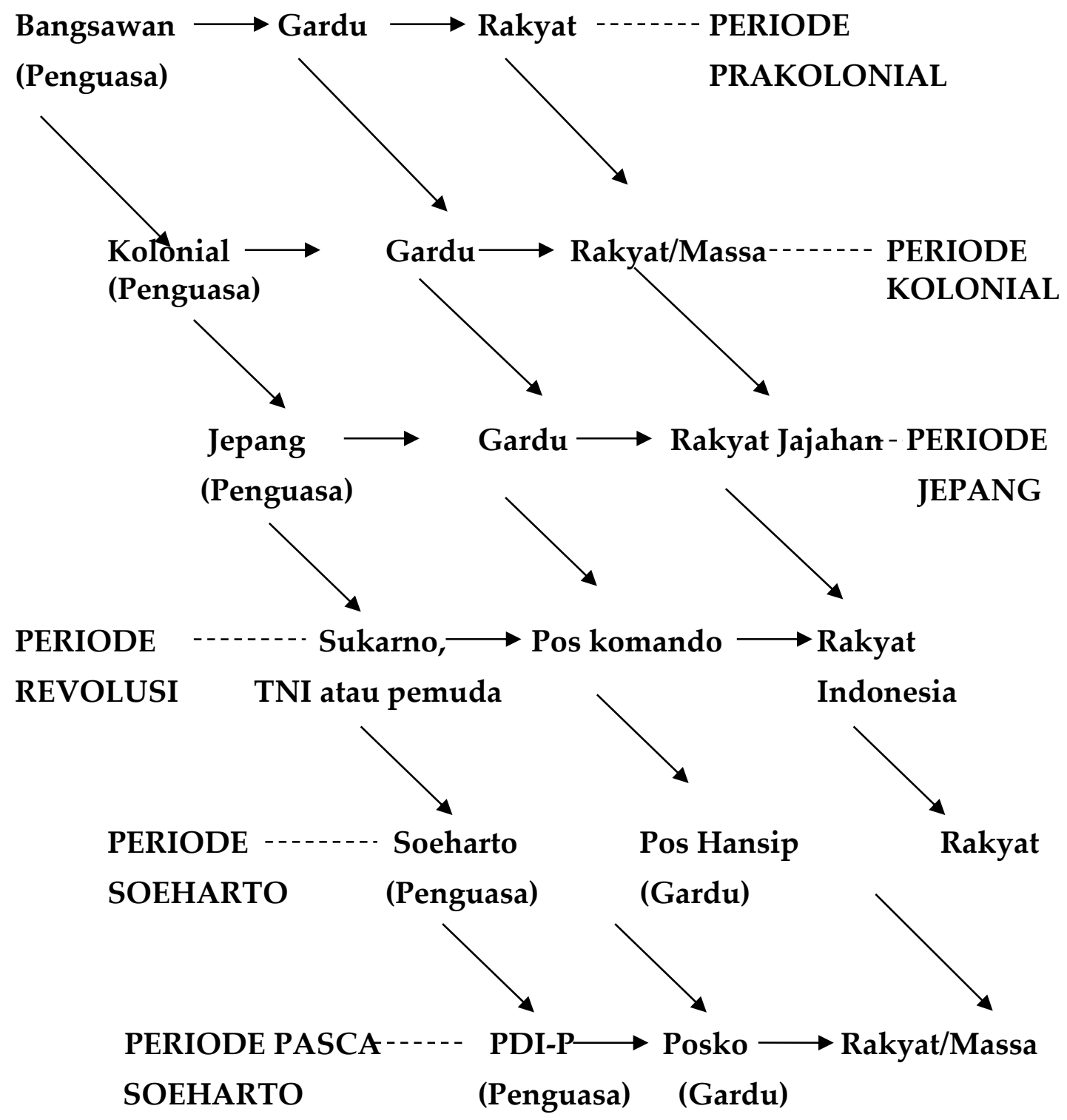

Ada Gardu; Aman atau Tidak Aman?

Selain struktur yang terbangun antara gardu dengan dengan penguasa, terdapat struktur lain bisa kita tangkap, yaitu yang terbentuk dari relasi antara gardu, keamanan-ketertiban, dan ketidakamanan.

Kehadiran gardu tidak hanya sebagai simbol keamanan, melainkan juga simbol ketidakamanan. Pembangunan gardu-gardu di kota era Soeharto didasarkan pada pemikiran bahwa ketidakamanan, yang ketika itu salah satu maksudnya komunisme tidak lagi berada di pedesaan, melainkan di perkotaan. Maka posko-posko militer ditarik dari desa ke kota. Sistem pengamanan bertransformasi dari posko militer menjadi pos-pos hansip. Pada era ini, gardu membangun struktur ingatan massa tentang adanya keamanan dan sekaligus ketidakamanan.

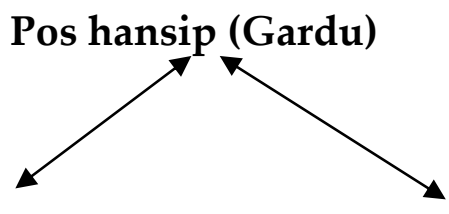




\section{Keamanan $\longleftrightarrow$ Komunisme dan budaya jalanan dan ketertiban (Ketidakamanan)}

Pasca Mei 1998, kekerasan politik dan aksi-aksi pembunuhan terjadi di berbagai tempat di Indonesia, seperti di Aceh, Kalimantan, Maluku dan Irian Jaya. Peristiwaperistiwa pengeboman juga terjadi di kota-kota besar di Pulau Jawa, Sumatra dan Bali. Sebagai reaksinya, penduduk di kota-kota besar di Jawa dan Sumatra mendirikan gardu-gardu atas biaya sendiri di hampir semua sudut jalan. Masyarakat Tionghoa pun demikian. Mereka membangun pagar dan gardu untuk lingkungan tempat tinggal mereka dan ikut serta dalam ronda malam. Dari fenomena tersebut, terlihat bahwa gardu memiliki relasi dengan dengan kekacauan; di sisi lain, gardu juga berelasi dengan keamanan dan ketertiban.

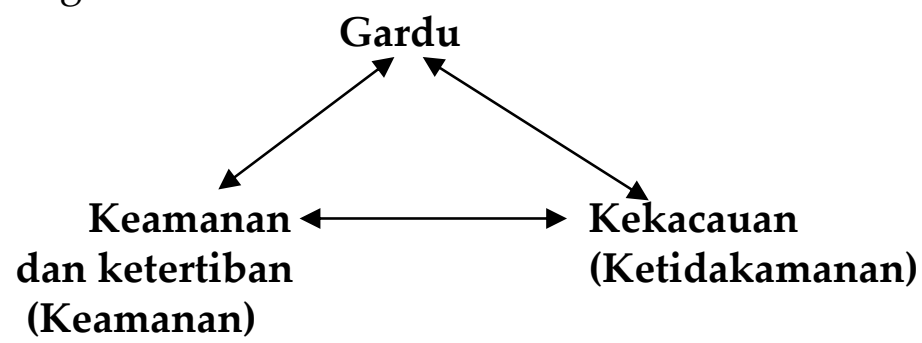

Sebab akibatnya tidak selalu demikian bahwa keberadaan gardu adalah mengamankan wilayah yang tidak aman. Kehadiran gardu-gardu di sepanjang Jalan Pos Besar justru mengundang perhatian para perampok. Sisi lain, kebutuhan akan jaminan keamanan dan ketertiban di sepanjang jalur Postweg lantas memendar pada keinginan negara untuk mengawasi gerakan orang-orang yang keluar masuk wilayah yang sudah terdaftar. Dengan adanya resiko keamanan, ronda rutin pertama kalinya dilembagakan demi menjaga kampung dan perkebunan serta memberikan jaminan keamanan bagi Postweg. Oleh karena itu, relasi yang terbangun diantara gardu kolonial, keamanan dan ketidakamanan berbentuk segitiga.

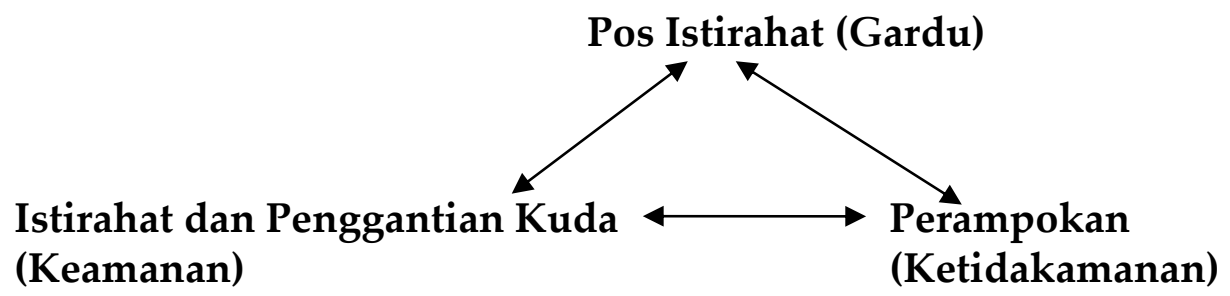

Berbeda dengan tiga zaman di atas, gardu di zaman Jepang justru mewakili ketidakamanan rakyat. Melalui gardu, Jepang melakukan pendisiplinan rakyat jajahan. Bahkan, gardu justru tampil sebagai ruang tidak aman itu sendiri. Hal ini karena perintah berhenti dan memberi hormat kepada penjaga sering menimbulkan hukuman yang berupa tamparan, tendangan dan pukulan bagi yang melakukan kesalahan, meskipun hanya sepele. Gardu sebagai penjaga keamanan hanya versi penguasa. Keamanan itu tidak ditemukan oleh rakyat. Namun struktur yang bisa 
digambar terkait dengan persoalan keamanan dan ketidakamanan pada gardu masa Jepang tetap segitiga.

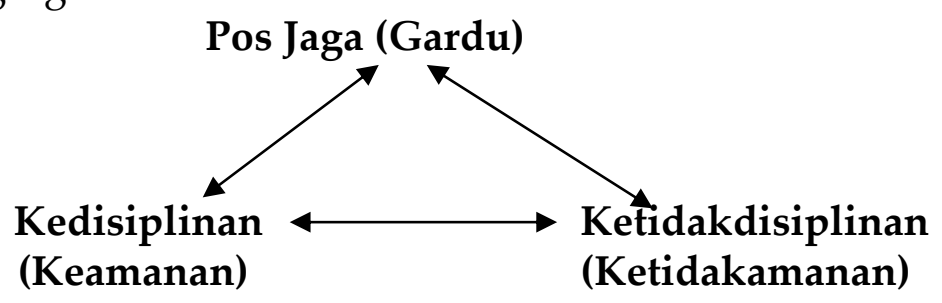

Praktek gardu masa Jepang ternyata sangat berpengaruh terhadap praktek penguasaan ruang yang dilakukan oleh TNI dan pemuda pada masa revolusi. Kehadiran pemuda di kota dengan semangat yang meniru penjaga-penjaga di bawah pendudukan Jepang mengingatkan kita pada citra para penjaga keamanan yang tengah berdiri di pos gardu. Model penjagaannya pun sama mirip dengan penjaga masa Jepang. Abidin Kusno menguatkan persepsi tentang kesamaan ini dengan gaya para pemuda dengan pertanyaan yang kerap mereka ajukan, yaitu: "mana surat keteranganmu, Bung?". Seperti penjaga di gardu, pemuda memeriksa identitas politik orang-orang yang mereka jumpai dan berhak memutuskan mana kawan-mana lawan.

Identitas pemuda sebagai penjaga negara, penjaga desa, penjaga kota telah menempatkan pos-pos komando yang mereka ciptakan sebagai simbol keamanan dan ketidakamanan. Pemeriksaan yang mereka lakukan juga menghadirkan rasa aman pada sebagian orang, dan rasa tidak aman untuk sebagian yang lain yang berada pada posisi lawan atau bahkan yang "abu-abu". Oleh karena itu, relasi antara gardu, keamanan dan ketidakamanan tetap membentuk struktur segitiga, seperti di bawah ini.

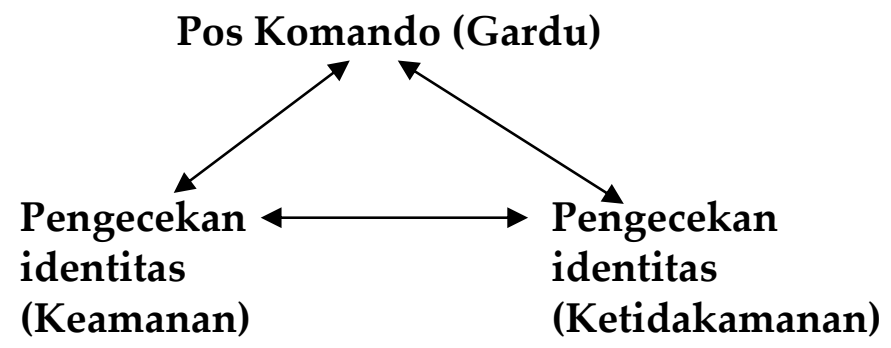

Struktur segitiga gardu juga terlihat mengalami transformasi dari waktu ke waktu. Transformasi itu saya coba gambarkan melalui struktur di bawah ini. Struktur yang dibangun berdasarkan urutan waktu masa kolonial, Jepang, Soeharto dan pascaSoeharto. Urutan yang sama dengan struktur transformasi gardu sebelumnya. Namun, berbeda dengan relasi yang terbangun antara gardu, penguasa, dan rakyat yang telah ada sejak zaman pra kolonial, struktur segitiga yang terbangun dalam memori massa tentang gardu, keamanan dan ketidakamanan tidak berawal dari masa pra-kolonial. Pada masa tersebut, gardu tidak menjadi simbol keamanan dan ketidakamanan. Dia bukanlah batas teritorial maupun untuk pertahanan dan pengusiran. Gardu-gardu koloniallah yang berfungsi sebagai fasilitas kenyamanan dalam perjalanan, dan sekaligus mengundang ketidakamanan karena gardu tersebut 
perhatian perampok. Maka, transformasi gardu yang bisa digambarkan terkait dengan keamanan dan ketidakamanan dimulai dari masa kolonial.

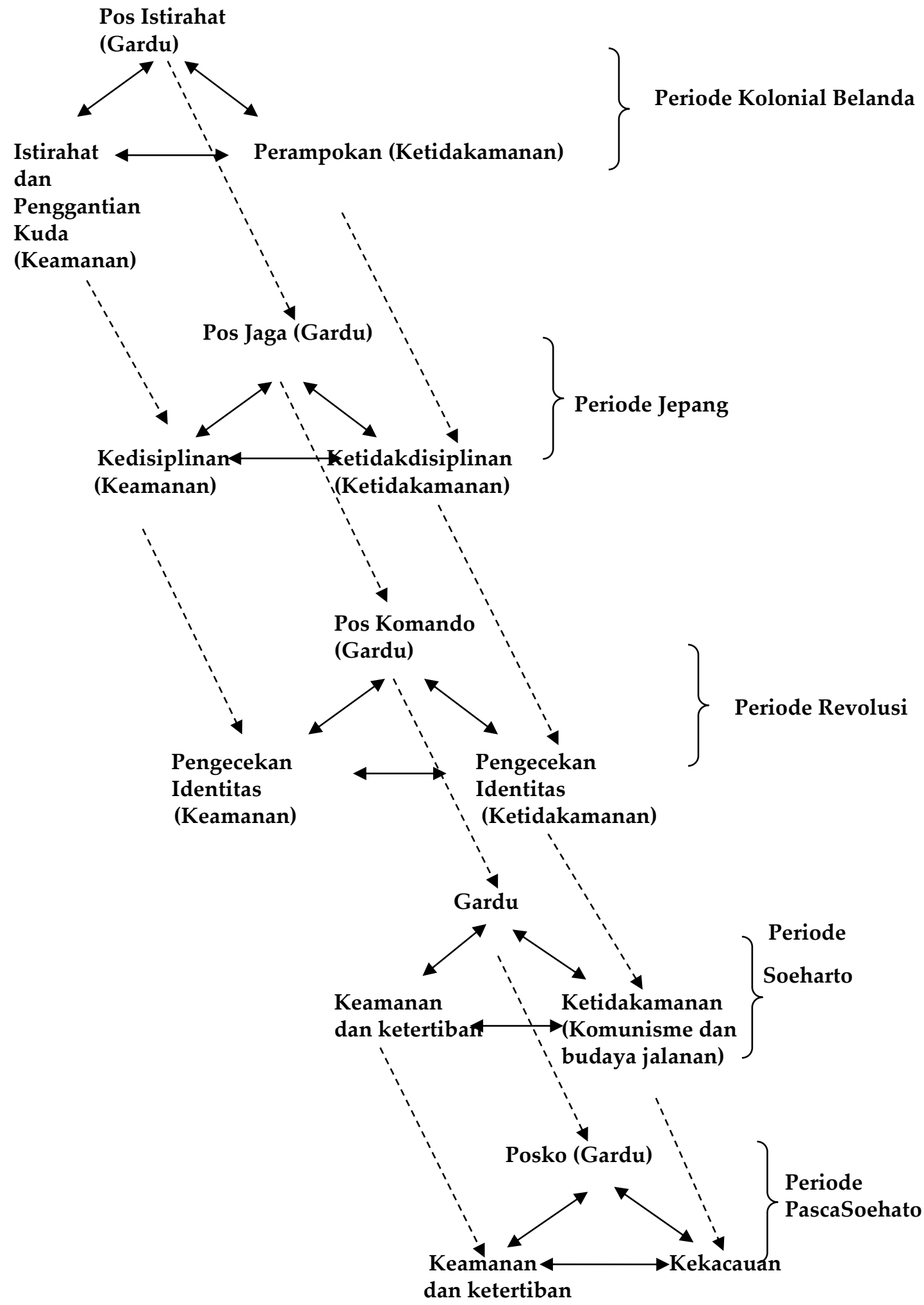

\section{GARDU DAN PENGUASAAN RUANG}


Posko yang menurut Abidin Kusno seringkali didirikan tanpa izin penduduk lokal, seakan-akan menjadi penanda teritorial. Bendera-bendera yang dipasang di sebagian "posko-posko Megawati" seolah menyatakan pesan, "ini adalah wilayah Banteng". Abidin Kusno bahkan juga melihat posko-posko dan bendera PDI-P ikut meramaikan kapitalisme pasar. Mereka bersaing dengan plakat-plakat besar dan iklan-iklan yang tersebar di seantero kota. Keduanya mencari bentuk dan hak untuk tampil bersama-sama di kota. Perebutan ruang kota seolah-olah terjadi antara pasar dan politik Megawati. Relasi itu bisa digambarkan sebagai berikut:

Relasi yang terjadi antara gardu dan ruang-ruang kota adalah relasi simbolis. Gardu adalah penanda atas ruang tertentu. Pasca-Soeharto, kehadiran gardu-gardu PDI-P memberikan tanda pusat-pusat massa partai tersebut.

Pada masa prakolonial, gardu yang terletak di depan rumah-rumah bangsawan adalah penanda atas ruang bangsawan tersebut. Meskipun tidak menghadirkan ruang kekuasaan atas suatu wilayah dengan batas-batas yang jelas, namun gardu tetap tidak lepas dari fungsinya sebagai penanda atas ruang, yaitu rumah bangsawan.

Groote Postweg dan gardu pendhopo mereorientasikan pola-pola pemukiman dan perhatian penduduk yang tinggal di sepanjang jalan itu. Dengan demikian, terciptalah suatu pusat yang baru. Mobilitas orang yang memancing perlunya pengawasan terhadap orang yang keluar masuk wilayah yang terdaftar, pada perkembangannya dibuatlah rancangan induk (a master plan) untuk mengelompokkan rumah-rumah sekaligus pekarangannya yang tesebar ke dalam pemukiman-pemukiman yang terpusat. Abidin Kusno mengutip kajian Jan Breman tentang perencanaan pengelompokan rumah-rumah di Jawa Barat.

Gardu yang didirikan di pintu masuk dari jalan utama memberikan semacam hubungan bagi "komunitas desa". Sebelumnyam tidak ada garis batas wilayah yang jelas dimana orang bisa melandaskan pernyataan yang kuat tentang "komunitas desa". Jaringan gardu telah menopang batas-batas yang jelas "komunitas desa". Dengan demikian, penegasan atas ruang fisik ditandai dengan gardu. Dengan ruang fisik yang jelas, pemerintah dengan mudah mencatat peningkatan "kelas pengelana" pada 1870 dan aktivitas-aktivitas kecu (bandit pedesaan) yang "mengganggu" ketertiban dan kedamaian desa. Residen Surakarta, Zoutlief, bahkan sudah melembagakan ronda dan membangun "komunitas tergerbang" (gated communities) yang dibuat untuk "menutup pintu masuk ke wilayah pelataran desa". Menjelang awal abad ke-20, kesatuan yang dibayangkan dari sebuah "komunitas desa", citra gardu sudah sepenuhnya terwujud dan ada di kota.

Meskipun gardu pada masa tersebut terlihat sebagai simbol otonomi lokal, namun sebenarnya gardu tidak bisa dilepaskan dari jaring-jaring politik negara kolonial. Penguasa lokal menyesuaikan gardu untuk melayani tujuan-tujuan mereka seturut prinsip organisasi kekuasaan kolonial.

Hal yang mirip terjadi di era Soeharto. Melalui pos-pos hansip, batas-batas sosial dan lingkungan dipancangkan. Mereka yang tinggal di belakang pos hansip adalah "orang dalam", sedangkan orang-orang yang berseliweran di jalanan merupakan "orang luar".

Berakhirnya era Soeharto, berakhir pula jaringan negara yang terbangun melalui pos hansip. Namun, strukturnya masih tegak berdiri dan fungsinya pun mengalami transformasi. Para individu dan komunitas menggunakannya untuk 
menjaga diri, keluarga dan harta benda mereka. Etnis Tionghoa yang menjadi sasaran amok massa melindungi diri mereka dengan membangun gardu-gardu. Inisiatif pembangunan ruang-ruang ditandai dengan gardu.

Periode Pemerintahan Militer Jepang secara jelas terlihat relasi antara gardu dan ruang. Gardu-gardu jaga yang diciptakan Jepang serta praktik-praktik pendisiplinan bagi yang melewatinya menciptakan ruang kekuasaan Jepang.

Awal kemerdekaan, Tentara Nasional Indonesia/TNI mendirikan "pos-pos komando" sebagai tempat pemeriksaan sekaligus merupakan tapal-tapal batas wilayah negara Indonesia. Para pemuda yang menempatkan diri mereka sebagai penjaga bangsa menempatkan praktek gardu masa Jepang ditumpahkan pada masa revolusi. Para pemuda tersebut bisa jadi merupakan bagian dari TNI, bisa jadi milisimilisi lepas. Mereka membangun ruang-ruang RI.

Transformasi relasi antara gardu dan ruang yang "dibangunnya" bisa digambarkan melalui struktur dibawah ini.

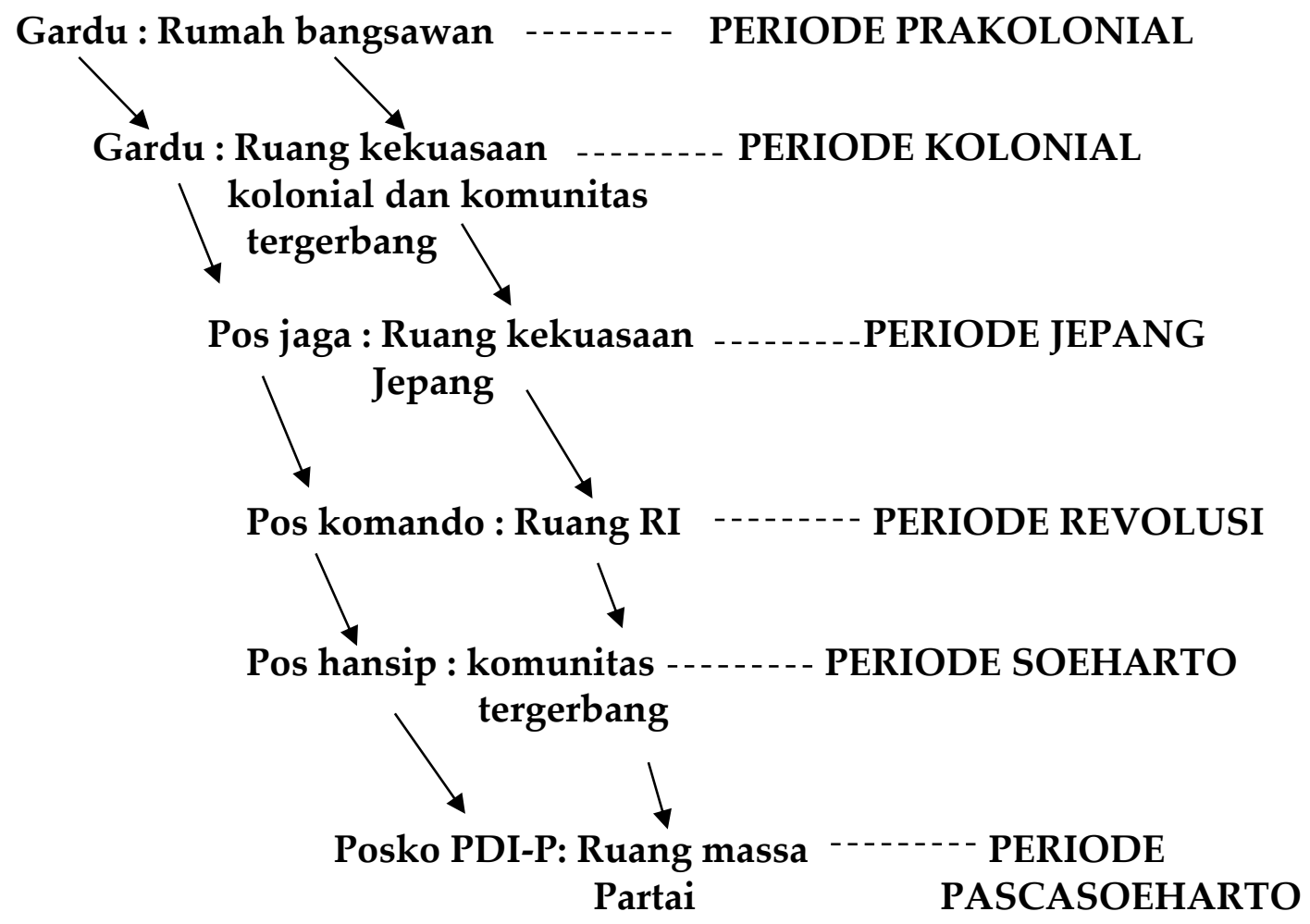

\section{Bentuk Gardu}

Bentuk gardu di desa dan di kota menunjukkan wajah yang berbeda. Gardugardu di desa dibangun sederhana, terbuat dari bambu, papan dan beratan jerami. Sedangkan gardu di kota seringkali merupakan banggunan permanen. Ia mirip sebuah rumah sempit yang terbuat dari batu-bata dan tidak jarang diberi sebuah bangku panjang di dalam atau di luarnya. Bahkan di kota-kota besar, gardu terkadang dibangun dengan menggunakan berbagai gaya yang rumit, dengan motif-motif barok atau anasir-anasir arsitektur Jawa. Pada umumnya mereka yang ikut jaga malam dipersenjatai sebilah bambu panjang dengan ujung yang dibentuk seperti garpu, tombak dan terkadang belati atau parang, namun tidak senjata api. Dari bentuknya, 
perpindahan gardu dari desa ke kota menunjukkan suatu transformasi identitas atas bangunan kecil ini. Transformasi itu bisa digambarkan seperti struktur di bawah ini.

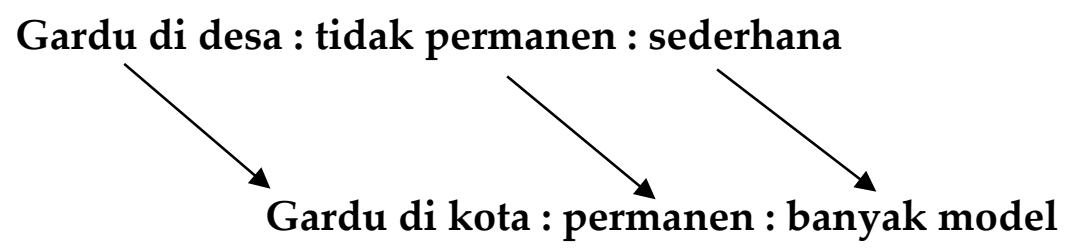

Di era Soeharto, pos-pos komando militer yang semula berada di wilayahwilayah pedesaan berfungsi sebagai pengendali aspek-aspek kehidupan sosial dan politik di lapangan demi menjamin ketertiban dan keamanan. Ketika militer ditarik ke kota dan bertransformasi menjadi pos-pos hansip, bersamaan dengan itu pos-pos atau gardu-gardu tersebut memiliki fungsi yang kompleks. Ia buka sekedar gardu penjagaan ruang tempat ia berada, melainkan menjadi milik negara. Dengan wacana keamanan dan ketertiban yang merasuk di alam pikiran warga kota, pada 1990-an pos hansip yang menyatu dengan gedung-gedung dan lingkungan-lingkungan pemukiman telah menjadi corak perkotaan yang sudah tidak asing lagi.

Pemaknaan pemindahan gardu dari desa ke kota tidak hanya dilihat pada era Soeharto. Penempatan gardu-gardu Belanda sepanjang Jalan Pos Besar merupakan suatu bentuk pindahnya gardu dari desa ke kota. Jalan Pos Besar merupakan proses penciptaan ruang-ruang kota di era kolonial. Gardu-gardu itu tidak dibangun sederhana, melainkan mengambil bentuk pendhopo yang merupakan identitas rumah bangsawan. Bentuk yang berwibawa di mata masyarakat Jawa pada masanya.

Gambaran gardu di kota pada masa kolonial ditampilkan Abidin Kusno melaui gambar gardu yang berdiri di jalan yang menghubungkan antara daerah Weltevreden dan Meester Cornelis sebelum 1880. Gardu itu terbuat dari bahan-bahan bangunan permanen, diukir dan diposisikan agar tampak seperti monumen sehingga mudah dilihat dari jauh.

\section{HISTORISISME STRUKTURAL (?) DALAM ARUS “POSMODERNISME”}

Sangat historis, adalah kesimpulan atas buku Penjaga Memori; Gardu di Perkotaan Jawa. Struktur transformasi atas gardu yang saya bangun di atas menjadi bukti bahwa tulisan Abidin Kusno sangat historis. Ciri lain sebelum struktur transformasi itu saya temukan, penelusuran atas asal-usul gardu dalam perjalanannya di ruang politik Indonesia telah menunjukkan bahwa tulisan Abidin Kusno tersebut adalah tulisan sejarah. Penelusuran asal usul adalah ciri utama dari sifat historis tersebut. Penekanan waktu pada setiap fenomena juga merupakan ciri yang ditekankan. Melalui pengetahuan tentang waktu inilah transformasi gardu dari periode ke periode bisa dipetakan. Dengan demikian, tulisan tersebut menggunakan dasar filsafat dan paradigma historisisme.

Meskipun struktur politik terkait dengan gardu dijelaskan dengan sangat menarik, namun karya tersebut tidak ditulis menggunakan paradigma strukturalisme Levi-Strauss. Abidin Kusno tidak menggunakan atau menetapkan suatu model atau pola tertentu yang diletakkan dari periode ke periode, melainkan lebih mengkaji fisik 
atau wajah gardu serta fungsi-fungsinya dengan menggunakan tafsir. Jadi tulisan tersebut sebagaimana tulisan sejarah yang lain, lebih dekat dengan hermeneutik. Interpretasi Abidin Kusno atas gardu merupakan sebuah tafsir penulis, bukan kesadaran dari si pembuat gardu. Struktur itu tersembunyi. Dia baru muncul ketika didekati dengan paradigma strukturalisme Levi-Strauss.

Sama-sama menggunakan strukturalisme Levi-Strauss, menganalisis tulisan sejarah dan menulis sejarah adalah dua hal yang berbeda. Menganalisis tulisan sejarah menggunakan strukturalisme Levi-Strauss lebih bisa dilakukan daripada menulis sejarah. Menganalisis tulisan sejarah sama halnya dengan menganalisis karya sastra yang bersifat historis. Karya Umar Kayam yang berjudul Para Priyayi, Sebuah Novel ${ }^{9}$ merupakan karya sastra yang sangat historis. Umar Kayam secara kronologis menghadirkan proses seseorang menjadi priyayi. Bahkan, transformasi dari Soedarsono atau Sastrodarsono ke Lantip diceritakan secara historis. Umar Kayam tidak menyadari adanya struktur-struktur yang terbentuk dalam ceritanya, namun ternyata strukturnya dapat ditemukan dengan menganalisisnya menggunakan strukturalisme Levi-Strauss. Jika demikian, sebuah karya sejarah tentunya memiliki nasib yang sama. Meskipun tidak ditulis dengan strukturalisme Levi-Strauss, yang berarti tidak menghadirkan struktur-struktur dari fenomena sejarah yang ditulis, namun karya itu bisa dibedah kembali untuk dicari strukturnya dengan menggunakan paradigma strukturalisme Levi-Strauss. Namun, bagaimana penerapan paradigma ini dalam menulis sejarah?

Dalam menulis sejarah, kita tidak bisa menerapkan metode kerja paradigma tersebut secara sempurna. Memang, paradigma ini bisa digunakan untuk membantu mencari atau membangun struktur atas fenomena-fenomena historis. Namun, yang bisa dilakukan hanya sampai pada penyusunan struktur-strukturnya, dan tidak bisa sampai pada deep structure. Jika kita melakukannya sampai pada deep structure berarti analisis yang kita lakukan tidak bersifat diakronis, melainkan sinkronis, yang berarti "perubahan" yang seharusnya berhasil dihadirkan oleh tulisan sejarah tidak akan tampak. Transformasi gardu dalam politik ruang di Indonesia terlihat ketika karya tersebut dianalisis kembali menggunakan paradigma strukturalisme Levi-Strauss. Namun, karya Abidin Kusno sendiri tidak menampilkan transformasi struktur gardu tersebut. Oleh karena itu, sub judul ini adalah "historisisme struktural" dengan tanda tanya dalam kurung (?) karena sebenarnya masih sebuah pertanyaan apakah dalam tulisan yang bersifat historis dengan struktur yang tidak secara real ditampilkan bisa disebut menggunakan historisisme struktural? Bukankah dalam historisisme struktural seharusnya transformasi atau perubahan yang terjadi selain ditampilkan melalui penjelasan, juga melalui diagram struktur?

Abidin Kusno juga mengetengahkan proses saling pengaruh antara monumen, memori kota, dan perjuangan simbolik dalam pencarian identitas dan kekuasaan. Sebenarnya gardu bukanlah bangunan yang dimaksudkan untuk menjadi monumen atau lokus peringatan. Sebagai suatu bangunan berukuran kecil, gardu tidak berada dalam struktur monumental. Oleh karena itu, peran gardu sering dilupakan. Namun, melalui tulisan tersebut, Abidin Kusno meletakkan gardu setara dengan monumen-

${ }^{9}$ Umar Kayam, Para Priyayi. Sebuah Novel (Jakarta: Grafiti, Cetakan III, 1992). 
monumen yang biasa digunakan untuk mengekpresikan pandangan-pandangan politik, memuat ingatan-ingatan masyarakat dan menentukan identitas teritorial dan kolektif. Melalui tulisan tersebut, Abidin Kusno mengingatkan kepada kita tentang peran institusi dan artefak sehari-hari dalam membentuk memori kota.

Tujuan penulisan sejarah gardu yang dilakukan Abidin Kusno adalah ingin menunjukkan bahwa ada satu cerita yang bisa disampaikan mengenai gardu yang akan membuat kita memikirkan keragaman dan keluasan sejarah Indonesia. Tujuan ini berarti mengarah pada memperkaya variasi sejarah. Kesadaran memperkaya variasi sejarah dan menangkap fenomena-fenomena kecil untuk ditulis merupakan efek dari berkembangnya pomodernisme di lingkungan ilmu sosial budaya.

Pengembangan variasi tema sejarah selain dipengaruhi oleh zaman, yaitu ketika wacana posmodernisme menjadi tren, juga telah dilontarkan oleh Kuntowijoyo melalui ide tentang demokratisasi sejarah. Gagasan tersebut berisi tentang pentingnya mengangkat tema-tema kecil sebagai tema sejarah karena menurut Kuntowijoyo, kalau sejarah hanya mengurus peristiwa besar dan orang besar, sejarah akan sangat miskin. Oleh karena itu, topik penulisan sejarah harus menyangkut peristiwa biasa, orang biasa dan pengalaman biasa. ${ }^{10}$

Semangat untuk menambah keragaman karya sejarah yang dikemukakan Abidin Kusno dalam Pengantar bukunya, dan gardu, si bangunan kecil, yang menjadi perhatiannya, saya maknai sebagai semangat demokratisasi sejarah. Menurut saya, hal itu merupakan efek dari arus posmodernisme yang berkembang dalam ilmu-ilmu sosial budaya. Dalam beberapa buku dikutip tulisan Keller, "Momen post-modern telah tiba dan intelektual, seniman, dan pengkaji kultural yang kebingungan berfikir apakah mereka harus ikut rombongan dan bergabung dengan karnaval ataukah menonton di pinggir lapangan hingga mode baru itu lenyap dalam pengasingan mode kultural". ${ }^{11}$

\section{KESIMPULAN}

Transformasi gardu pada politik ruang yang dimainkan penguasa dari periode ke periode yang disajikan Abidin Kusno sangat historis, namun analisisnya sangat strukturalis. Analisis strukturalis Abidin Kusno baru terlihat jelas ketika karya tersebut dianalisis kembali menggunakan paradigma strukturalisme Levi-Strauss. Masing-masing periode yang diteliti Abidin Kusno menampilkan pola yang sama. Struktur yang berhasil dibangun menunjukkan suatu pola, yang bisa dimaknai sebagai grammer dalam logika bahasa. Namun, pembentuk struktur itu tidak statis, dia mengalami transformasi, meskipun posisinya dalam struktur tidak berubah. Transformasi itulah yang menunjukkan terjadinya proses historis, terlebih ketika struktur-struktur yang ditemukan bisa dipetakan dalam suatu ruang dan waktu tertentu. Dengan demikian, analisis terhadap karya Abidin Kusno ini telah

${ }^{10}$ Kuntowijoyo, Selamat Tinggal Mitos, Selamat Datang Realitas. Esai-esai Budaya dan Politik. . Esai-esai Budaya dan Politik (Bandung: Mizan, 2002), hlm. 58-59.

${ }^{11}$ Ritzer, George dan Goodman, Douglas J., op. cit., hlm. 628, Perry Anderson, AsalUsul Posmodernitas (Yogyakarta, Pustaka pelajar, Cetakan II, 2008). 
membuktikan bahwa strukturalisme sangat bisa digunakan untuk menganalisis karya sejarah.

Menampilkan banyak warna, sepertinya tepat untuk menyimpulkan tulisan Abidin Kusno. Gardu, si bangunan kecil, menjadi tema yang menarik perhatiannya, merupakan efek arus posmodernisme. Namun, kecerdesannya untuk memetakan posisi gardu dalam konteks sejarah politik yang besar secara tersirat menunjukkan struktur yang dibangun tanpa kesadaran penguasa dan masyarakat. Inilah yang menggelitik pembaca tentang apakah tulisan tersebut bersifat strulturalis? Namun, pola-pola atau struktur-struktur yang ditampilkan Abidin Kusno dengan tanpa diagram itu bisa jadi bukanlah struktur yang secara sadar ditampilkan. Ada kemungkinan hal itu merupakan struktur yang terbangun dalam bawah sadar Abidin Kusno, dan baru ditemukan ketika karya tersebut dianalisis menggunakan paradigma strukturalisme Levi-Strauss.

Di sisi lain, pembacaan kembali terhadap karya Abidin Kusno tentang gardu menghadirkan dialog antara beberapa paradigma. Dengan demikian, diharapkan akan menghasilkan suatu jalan tengah yang saling mengisi antara paradigma yang satu dengan yang lain. Setiap dialog membawa konsekuensi uji coba dan hipotesahipotesa yang liar. Tanpa uji coba, sebuah pertanyaan pastilah akan menguap tanpa jawab; sedangkan hipotesis liar merupakan bentuk pembebasan diri dari kungkungan salah satu paradigma, dan itu adalah syarat terjadinya dialog.

\section{DAFTAR PUSTAKA}

Abidin Kusno, Behind the Postcolonial, Architecture, Urban Space and Political Cultures in Indonesia. London and New York, Routledge, 2000.

- Penjaga Memori; Gardu di Perkotaan Jawa. Yogyakarta: Ombak, 2008.

Ruang Publik, Identitas dan Memori Kolektif: Jakarta Pasca-Soeharto. Yogyakarta: Ombak, 2009.

Zaman Baru Generasi Modernis, Sebuah Catatan Arsitektur Yogyakarta: Ombak, 2012.

Agus Cremers, Antara Alam dan Mitos, Memperkenalkan Antropologi Struktural Claude Levi-Strauss. Flores: Penerbit Nusa Indah, 1997.

Badcock, Christopher R., Levi Strauss, Strukturalisme dan Teori Sosiologi. Yogyakarta: Pustaka Pelajar, Cetakan II, 2008.

Giddens, Anthony "Strukturalisme, Pos-Strukturalisme dan Produksi Budaya, Giddens, Anthony dan Turner, Jonathan, Social Theory Today. Panduan Sistematis Tradisi dan Tren Terdepan Teori Sosial . Yogyakarta: Pustaka Pelajar, 2008

Heddy Shri Ahimsa-Putra, "Dari Antropologi Budaya ke Sastra dan Sebaliknya”, Arif Rokhman, et. al., Sastra Interdisipliner. Menyandingkan Sastra dan Disiplin Ilmu Sosial. Yogyakarta: Qalam dan Forum Sastra Banding, 2003. 
Strukturalisme Levi-Strauss. Mitos dan Karya Sastra. Yogyakarta: Kepel Press, Cetakan Ketiga, 2013.

Kevin O’Donnell, Posmodernisme. Yogyakarta: Kanisius, Cetakan ke-5, 2013.

Kuntowijoyo, Pengantar Ilmu sejarah. Yogyakarta: Bentang, 1995.

Selamat Tinggal Mitos, Selamat Datang Realitas. Esai-esai Budaya dan Politik. . Esai-esai Budaya dan Politik. Bandung: Mizan, 2002.

Metodologi Sejarah. Yogyakarta: Tiara Wacana, Edisi Kedua, 2003.

Kuntowijoyo, Penjelasan Sejarah (Historical Explanation). Yogyakarta: Tiara Wacana, 2008.

Macdonell, Dianne, Teori-teori Diskursus. Kematian Strukturalisme dan Kelahiran Posstrukturalisme. Dari Althusser hingga Foucoult. Jakarta: Teraju, 2005.

Nordholt, Henk Schulte, Bambang Purwanto, dan Ratna Saptari (ed), Perpektif Baru Penulisan Sejarah Indonesia. Jakarta: Yayasan Obor Indonesia, KITLV-Jakarta, Pustaka Larasan, 2008.

Perry Anderson, Asal-Usul Posmodernitas. Yogyakarta, Pustaka pelajar, Cetakan II, 2008.

Ritzer, George dan Goodman, Douglas J., Teori Sosiologi Modern. Jakarta: Kencana Prenada Media Group, Edisi ke-6, Cetakan ke-5, 2008.

Umar Kayam, Para Priyayi. Sebuah Novel. Jakarta: Grafiti, Cetakan III, 1992. 